\title{
GOOGLE, PRÁVO BÝT ZAPOMENUT A LISTINA ZÁKLADNÍCH PRÁV EU ${ }^{1}$
}

\author{
JAROMÍR FRONC ${ }^{2}$
}

$\begin{array}{ll}\text { Soud: } & \text { Spolkový ústavní soud } \\ \text { Věc: } & \text { 1 BvR 276/17 } \\ \text { Datum: } & \text { 6. } 11.2019 \\ \text { Dostupnost: } & \text { bundesverfassungsgericht.de }\end{array}$

\section{1. ÚVOD}

Právo být zapomenut se v poslední dekádě stalo oblíbeným postmoderním právně-technologickým tématem. Vše odstartoval rozsudek Soudního dvora EU ve věci Google Spain, který v poměrech tehdejší směrnice 95/46/ES ${ }^{3}$ dovodil povinnost provozovatele vyhledávače na žádost vymazat z výsledku vyhledávání provedeného na základě jména osoby odkazy na webové stránky zveřejněné třetími osobami obsahující informace týkající se této osoby. ${ }^{4}$ Závěry SDEU byly následně zapracovány do čl. 17 obecného nařízení o ochraně osobních údajů ${ }^{5}$ který garantuje právo na výmaz.

Právem být zapomenut se loni zabýval německý Spolkový ústavní soud ve dvou rozhodnutích vydaných ve stejný den. Ta přinesla nejen určitou

1 Tento př́spěvek vznikl v rámci plnění projektu Specifického vysokoškolského výzkumu (SVV) Univerzity Karlovy č. 260494 „Integrující úloha lidských práv v současném právu“.

2 Jaromír Fronc, magisterský student Právnické fakulty Univerzity Karlovy. Kontaktní e-mail: jaromir.fronc@gmail.com.

3 Směrnice Evropského parlamentu a Rady 95/46/ES ze dne 24. ř́ijna 1995 o ochraně fyzických osob v souvislosti se zpracováním osobních údajů a o volném pohybu těchto údajů.

4 Rozsudek SDEU (velkého senátu) ze dne 13. 5. 2014, ve věci C-131/12, Google Spain (dále jen „Google Spain“). 
korekci judikatury SDEU, ale i obecnější závěry ohledně vztahu unijního a německého práva.

V prvním usnesení („Recht auf Vergessen $\left.I^{“}\right)^{6}$ se stěžovatel domáhal toho, aby byly z webových stránek novin Der Spiegel odstraněny články z let 1982 a 1983, které pojednávaly o jeho odsouzení pro trestný čin vraždy. Tento případ je specifický pro zvláštní ochranu, která je národním ústavním pořádkem přiznána médiím. Vzhledem $\mathrm{k}$ většímu komparativnímu přínosu pro českého čtenáře proto níže rozeberu usnesení druhé („Recht auf Vergessen II“), ve kterém bylo aplikováno výhradně unijní právo.

\section{SKUTKOVÝ STAV}

Televizní kanál Norddeutscher Rundfunk odvysílal 21. 1. 2010 díl pořadu Panorama s názvem Výpověd: Odporné triky zaměstnavatelů. V pořadu bylo zmíněno i jméno pozdější stěžovatelky (v rozhodnutí anonymizováno), která byla obviněna $\mathrm{z}$ nespravedlivého chování vưči zaměstnanci. Stěžovatelka pořadu poskytla rozhovor, ve kterém se k případu vyjádřila. Díl byl dostupný v online archivu NDR a zobrazoval se ve výsledcích vyhledávání Google při vyhledání jména stěžovatelky.

\section{PROCESNÍ HISTORIE}

Poté, co Google odmítl odkaz odstranit, se stěžovatelka obrátila na Zemský soud v Lüneburgu, který žalovanému rozsudkem z 22. 4. 2016 zakázal na stránku odkazovat, a to s odkazem na občanský zákoník, ${ }^{7}$ na právo na důstojnost a ochranu osobnosti podle Základního zákona, ${ }^{8}$ a také na $§ 35$ zákona o ochraně osobních údajů, ${ }^{9}$ který prováděl směrnici 95/46/ES, s přihlédnutím k rozsudku Google Spain.

Nařízení Evropského parlamentu a Rady (EU) 2016/679 ze dne 27. dubna 2016 o ochraně fyzických osob v souvislosti se zpracováním osobních údajů a o volném pohybu těchto údajů a o zrušení směrnice 95/46/ES (obecné nařízení o ochraně osobních údajů) [dále jen "GDPR"].

6 Usnesení BVerfG ze dne 6. 11. 2019, sp. zn. 1 BvR 16/13.

7 Bürgerliches Gesetzbuch, BGBl. I 2002, s. 42. Znění německých předpisů čerpám z beckonline.de.

8 Grundgesetz, BGBl. I 1949, s. 1.

9 Bundesdatenschutzgesetz, BGBl. I 2003, s. 66. 
Vyšší zemský soud v Celle k odvolání žalovaného 29. 12. 2016 po provedení vážení zájmů rozsudek změnil tak, že se žaloba zamítá. Proti tomuto rozhodnutí žalobkyně podala ústavní stížnost ke Spolkovému ústavnímu soudu, jehož první senát rozhodl usnesením z 6. 11. 2019 tak, že se stížnost zamítá.

\section{APLIKOVATELNOST LZPEU}

Spolkový ústavní soud konstatoval, že právní úprava je plně harmonizovaná unijním právem. ${ }^{10}$ Citoval judikaturu SDEU, podle kterého směrnice 95/46/ES nepředstavuje minimální harmonizaci, nýbrž vyžaduje jednotné provedení a aplikaci v rámci EU, ${ }^{11}$ což bylo později potvrzeno i přijetím GDPR. ${ }^{12} \mathrm{~V}$ takové situaci pro soud nejsou referenčním kritériem základní práva vyplývající z národního ústavního pořádku, nýbrž základní práva vyplývající z unijního práva. ${ }^{13}$ Při výkladu unijního práva nelze ke Základnímu zákonu ani přihlížet, mj. proto, že takový výklad by mohl být mylně považován za správnou interpretaci i pro ostatní členské státy EU. ${ }^{14}$

Ustanovení směrnice 95/46/ES musí být v rozsahu, v němž upravují zpracování osobních údajů, které může představovat zásah do základních svobod, a zejména práva na soukromí, nutně vykládána ve světle základních práv, která jsou nyní zakotvená v LZPEU. ${ }^{15,16}$ Tato práva se uplatní nejen ve vztazích mezi jednotlivcem a státem, ale i ve vztazích horizontálních. ${ }^{17}$

10 Bod 33 anotovaného rozhodnutí.

11 Bod 39 anotovaného rozhodnutí. K metodám harmonizace viz KRÁL, Richard. Směrnice EU z pohledu jejich transpozice a vnitrostátních účinků. 1. vydání. Praha: C. H. Beck, 2014, s. 6672.

12 Bod 40 anotovaného rozhodnutí.

13 Body 42-43 anotovaného rozhodnutí.

14 Bod 45 anotovaného rozhodnutí.

15 Listina základních práv Evropské unie, uznaná čl. 6 odst. 1 Smlouvy o Evropské unii jako součást primárního práva EU.

16 Bod 95 anotovaného rozhodnutí odkazující se mj. na Google Spain, bod 68.

17 Bod 96 anotovaného rozhodnutí. 


\section{VÁŽENÍ ZÁJMŮ}

Soud se následně věnoval samotnému porovnání jednotlivých konkurujících si práv a zájmi̊. Na straně stěžovatelky došlo k zásahu do práva na respektování soukromého a rodinného života (čl. 7 LZPEU) a práva na ochranu osobních údajů (čl. 8 LZPEU). ${ }^{18}$ Tato práva spolu úzce souvisí, ${ }^{19}$ což platí obzvlášt při zpracování osobních údajů prováděném provozovatelem vyhledávače. ${ }^{20}$

To nejsou nijak převratné závěry, mnohem zajímavější však je, co soud položil na opačnou misku vah. Primárně tu je žalovaná společnost Google, které svědčí svoboda podnikání (čl. 16 LZPEU). ${ }^{21}$ Svoboda projevu (čl. 11 LZPEU) se na ni zde však nevztahuje, nebot’ byt výsledky vyhledávání nejsou obsahově neutrální a mohou ovlivnit mínění uživatelů, vyhledávač není určen k šíření konkrétních názorů a sám se popisuje jako nezávislá služba, která se snaží co nejvíce uspokojit potenciální zájmy uživatelů. ${ }^{22}$

Při poměřování však musí být zohledněna práva třetí osoby - tvůrce obsahu. ${ }^{23}$ Pokud je totiž zákaz zobrazování výsledku vyhledávání vydán vůči konkrétnímu obsahu, tvưrce je tím připraven o důležité médium pro jeho rozšiřování, které by jinak měl k dispozici, čímž se omezuje jeho svoboda projevu. ${ }^{24}$

Stejně tak musí být zváženy i informační zájmy uživatelů. Zde se nicméně nejedná o práva jednotlivých uživateli̊, nýbrž o obecný princip svobody informací podle čl. 11 LZPEU. ${ }^{25}$ Přičemž zatímco ekonomickým

\footnotetext{
18 Bod 98 anotovaného rozhodnutí.

19 Bod 99 anotovaného rozhodnutí odkazující se mj. na rozsudek SDEU (velkého senátu) ze dne 9. 11. 2010 ve spojených věcech C-92/09 a C-93/09, Volker und Markus Schecke GbR a Hartmut Eifert, bod 47.

20 Bod 99 anotovaného rozhodnutí odkazující se mj. na Google Spain, bod 80.

21 Body 103-104 anotovaného rozhodnutí.

22 Bod 105 anotovaného rozhodnutí.

23 Body 108-109 anotovaného rozhodnutí.

24 Takto argumentovala již KATSIREA, Irini. Search Engines and Press Archives Between Memory and Oblivion. European Public Law. 2018, roč. 24, č. 1, s. 128-129.

25 Bod 110 anotovaného rozhodnutí odkazující se mj. na Google Spain, bod 81.
} 
zájmům provozovatele vyhledávání soud nepřiznal velkou důležitost, ${ }^{26}$ na informační zájmy veřejnosti a práva tvưrců klade větší dưraz. ${ }^{27}$ Stěžejním východiskem vážení zájmů pak je, že se nevychází z domněnky přednosti osobnostních práv; konkurující si práva musí být spravedlivě porovnána. ${ }^{28}$

Při aplikaci výše uvedených postulátů na konkrétní případ Spolkový ústavní soud zdůraznil, že odvysílaný pořad se nezabýval čistě soukromým životem stěžovatelky, nýbrž otázkami, které byly předmětem veřejného zájmu a stále jsou (byt̉ se snižující se intenzitou). V prostředí Internetu ovšem určitému překryvu mezi osobním a profesním životem nelze zabránit. ${ }^{29}$ Pro soud bylo také důležité, že sama stěžovatelka souhlasila s poskytnutím rozhovoru, aniž by $\mathrm{k}$ tomu byla jakkoliv dotlačena či donucena. ${ }^{30}$ Název odvysílaného dílu (Odporné triky zaměstnavatelů) byl př́ípustným hodnotícím soudem, což platí i pro další rozšiřování tohoto kritického titulku prostřednictvím Internetu. ${ }^{31}$ Pokud jde o faktor času, pro soud bylo rozhodné, že stěžovatelka do nynějška působí jako jednatelka a stále existuje veřejný zájem ohledně tématu pořadu - v tomto ohledu není období 7 let excesivní. ${ }^{32}$ Došel tedy k závěru, že Google nemá povinnost odkaz odstranit.

\section{DISKUSE}

Anotované rozhodnutí vzbudilo poměrně bouřlivé ohlasy, které se však primárně zabývaly otázkou vztahu ústavního a unijního práva. Spolkový německý soud totiž dosud se základními právy Evropské unie v podstatě neoperoval. Jeho rozhodnutí $\mathrm{k}$ právu být zapomenut tak přinesla dva podstatné závěry: soud se jednak přihlásil $\mathrm{k}$ tomu, že bude sám LZPEU aplikovat, jednak provedl „jednoznačný řez“, kdy tak bude činit. Rozlišil na

26 Shodně Google Spain, bod 81.

27 Bod 120 anotovaného rozhodnutí.

28 Bod 121 anotovaného rozhodnutí.

29 Bod 128 anotovaného rozhodnutí.

30 Bod 129 anotovaného rozhodnutí.

31 Bod 130 anotovaného rozhodnutí.

32 Bod 134 anotovaného rozhodnutí. Soud zde má zřejmě na mysli období do rozhodnutí odvolacího soudu. 
jedné straně situaci, na kterou dopadá přímo použitelný předpis EU (případně prováděcí předpis, při jehož přijímání však německý zákonodárce neměl prostor pro uvážení) - a referenční rámcem přezkumu je tak výhradně LZPEU - a na druhé straně aplikaci národního práva, které nepodléhá plné unijní harmonizaci - a referenční rámcem je tudíž primárně Základní zákon. Německá jurisprudence závěry rozhodnutí v zásadě kvitovala, byt’ si také povšimla, že si tím soud zároveň ve vlastním zájmu vytvořil podmínky $\mathrm{k}$ tomu, aby nebyl opomíjen při interpretaci a aplikaci stále narůstajícího objemu unijní právní regulace. ${ }^{33}$

Čtenář si tak zřejmě nejprve položí otázku, zda by měl podobný řez učinit také český Ústavní soud. Ten sice s LZPEU operuje, ale žádný jednoznačný návod pro její použití v judikatuře nenalezneme, přičemž obecně je akcentována především povinnost eurokonformního výkladu. ${ }^{34}$ Setkáváme se spíše se syntetickou metodou, kdy Ústavní soud ověřuje, že bylo dosaženo standardu ochrany podle všech relevantních lidskoprávních dokumentů. Metoda jistě logická a pochopitelná, ale obtížněji použitelná ve chvíli, kdy je třeba poměřovat proti sobě stojící základní práva. Ústavní soud svůj postoj příliš nevyjasnil ani v nedávném nálezu, kde anotované rozhodnutí výslovně citoval. ${ }^{35} \mathrm{Z}$ jeho odůvodnění se totiž nepodává, že by byl připraven rozhodovat čistě na základě LZPEU, nýbrž se zde opět mluví pouze o (eurokonformním?) výkladu práva.

Pro naše potřeby je ovšem použití LZPEU v anotovaném rozhodnutí užitečné především tím, že soudu umožnilo dospět $\mathrm{k}$ závěrům ve věci samé, které - pokud můžeme Spolkovému ústavnímu soudu věřit, že se oprostil

${ }^{33}$ BREUER, Marten. Wider das Recht auf Vergessen ... des Bundesverfassungsgerichts! In: Verfassungsblog [online]. 2. 12. 2019. [cit. 31. 3. 2020]. Dostupné z: https://verfassungsblog.de/wider-das-recht-auf-vergessen-des-bundesverfassungsgerichts/. KARPENSTEIN, Ulrich, KOTTMANN, Matthias. Vom Gegen- zum Mitspieler - Das BVerfG und die Unionsgrundrechte. Europäische Zeitschrift für Wirtschaftsrecht. 2020, roč. 31, č. 5, s. $185-189$.

${ }^{34}$ Srov. BOHÁČEK, Lukáš. Součástí referenčního rámce a kritériem přezkumu Spolkového ústavního soudu bude do budoucna rovněž Listina základních práv Evropské unie. Bulletin oddělení analytiky a srovnávacího práva. [online]. 2019, roč. X, č. 4, s. 5-7. [cit. 31. 3. 2020]. Dostupné z: http://www.nsoud.cz/judikatura/ns_web.nsf/0/A127C1166CE3E527C1 2584E1003BC6BD/\$file/Bulletin\%20\%5B2019\%5D\%204.pdf.

35 Nález Ústavního soudu ze dne 11. 2. 2020, sp. zn. Pl. ÚS 4/17, bod 109. 
od německého práva - mohou být použitelné i pro ostatní členské státy EU, a to i pro v současnosti účinný čl. 17 GDPR. To ovšem s výhradou, že konečný výsledek poměřování se $\mathrm{v}$ různých členských státech může beztak lišit. $^{36}$

Rozsudek Google Spain v závěru postuluje, že osobnostní práva podle čl. 7 a 8 LZPEU převládají „v zásadě nejen nad hospodářským zájmem provozovatele vyhledávače, ale rovněž nad zájmem veřejnosti nalézt uvedenou informaci při vyhledávání prováděném na základě jména subjektu údajů. “37 Anotované rozhodnutí $\mathrm{v}$ zásadě jde $\mathrm{v}$ těchto šlépějích, avšak zároveň přináší určité posuny. Na rozdíl od judikatury SDEU výslovně zmiňuje čl. 11 a 16 LZPEU a nově uvádí i nutnost zohlednit práva tvưrce. Pokud tedy dotčené osoby tvrdí, že provozovatel webového vyhledávání by měl přestat poskytovat informace o určitém obsahu Internetu a odkazovat na něj, musí se osobnostní práva dotčených osob poměřit se základními právy př́slušných tvůrců obsahu a informačními zájmy uživatelů Internetu, a to v rámci svobody podnikání provozovatelů vyhledávání.

Zároveň však zdůrazňuje, že přípustnost zveřejnění samotného obsahu a přípustnost odkazování na něj ve výsledcích vyhledávání musí být poměřovány $\mathrm{v}$ samostatných testech. ${ }^{38}$ Nadále tedy platí, že provozovateli vyhledávače může být $\mathrm{v}$ některých případech zakázáno odkazovat na obsah, jehož zveřejnění na odkazované stránce je samo o sobě v souladu se zákonem. $^{39}$

Z výše uvedené citace SDEU by se také mohlo zdát, že osobnostní práva dotčených osob mají prima facie navrch a nutnosti výsledky odstranit se tak dá vyhnout jen s poukazem na specifické okolnosti př́padu. Rozhodnutí $\mathrm{z}$ Karlsruhe je tak třeba ocenit i proto, že explicitně stanoví povinnost

36 Rozsudek SDEU (velkého senátu) ze dne 24. 9. 2019, ve věci C-507/17, Google LLC v. CNIL, bod 67.

${ }^{37}$ Google Spain, bod 99.

38 Body 112-119 anotovaného rozhodnutí. K této dvojkolejnosti viz též NONNEMANN, František. Základní analýza rozhodnutí Soudního dvora EU ve věci internetového vyhledávače Google. Právní rozhledy. 2014, roč. 22, č. 13-14, s. 484-485.

39 Srov. Google Spain, bod 88. 
konkurující si základní práva porovnat bez jakýchkoliv předsudečných úvah.

Toto dílo lze užít v souladu s licenčními podmínkami Creative Commons BY-SA 4.0 International (http://creativecommons.org/licenses/by-sa/4.0/legalcode). 